\title{
The Guidi and their Relations with Florence
}

\section{I.-Froj the tenth century to the death of Guido}

\section{IL IHARCHESE.}

THE influence of noble families can be studied in all the parts of 1 western Europe where the invasion of the barbarians superimposed a new stratum of landowners on the tillers of the soil, bat nowhere better than in northern Italy, where the conditions of life continued unstable, and where the sense of municipal life, fed through classic traditions, never died out. On one side there was an absence of centralised authority which left room for powerful individualities to develop; on the other there was a continued stimalas to family feeling, through the efforts made by the growing communes to throw off their yoke. The history of medisoval Italy is largely bound up in the history of its families, and among these families were the Guidi, who at one time took rank as the most powerful lords of Tuscany. Their annals go back to the tenth century, and their history has repeatedly engrossed attention, partly owing to their connexion with the rise of the city of Florence, partly because Dante referred to various members of the family, and was in personal relation to some of them. When we first come across these counts they were independent landowners, the founders of monsateries, the protectors-often the tyrants - of the lesser cities. As time went by they attained the power of barons and ranked among the chief feudatories of the emperors. Then we find them in conflict with the rising cities, especially with Florence. But when the difficulties in the executive tore the cities into factions, a new field was opened to their infuence, and they played important parts in the struggles between the Guelfs and the Ghibellines.

That the Guidi were Lombards by descent is proved by claims made by them in 1043 and again in 1097 to act in accordance with Lombard law. The Lombards had brought with them their own conceptions of right and justice, and embodied them in a code of laws according to which they lived without forcing them on general acceptance. When the rule of the Lombards was followed by that of the Franks, these in turn brought their own law, which 
many Frankish families followed. At the same time customs supported by Roman law continued in force among the mass of the people. The result was a clashing of ideas about right and wrong which brought with it endless confusion and which reached its climax in the tenth century, when the Frankish empire collapsing on itself had left room for the rulers of the various Italian provinces to strive for autonomy. 'Let customs yield to authority; let law and reason dispel depraved usages,' was the repeated call of Ratherius ( +974$)$, bishop of Verona. It was a call which found an echo in other writings of the time.

At this period we first hear of the Guidi. A legendary colouring is given by early chroniclers to the opening chapter of their history, but the essentials of this chapter are corroborated by contemporary references. They were the owners of extensive property near the city of Pistoja in Tuscany at a time when Count Tegrimo ( $\uparrow$ c. 942), the first member of the family known by name, acquired the great atronghold of Modigliana, in the Romagna. It is the Castrum Mutilum mentioned by Livy. Count Tegrimo, according to the account of the chronicler Tolosanus ( $\uparrow 1226)$, went hunting in the Apennines at a time when Engelrada, the danghter of Duke Martino of Ravenna, was holding court at Modigliana. He presented the lady with a stay he had killed, he won her favour and he married her.' Several chartors prove that Engelrada was a person of influence at Ravenna, ${ }^{2}$ where the Guidi gained a footing in consequence of the marriage.

During the Frankish rule the province of Tuscany was governed by marquises whose residence was at Luccs. They wore appointed by the emperor, and the lesser barons, such as the Guidi, stood in the relation of followers to them. In the year 926 , however, Hugo of Arles ( $\dagger 946)$, asserted the claims of an independent sovereign. He set aside his balf-brother-who was marguis of Tuscany-and was crowned king of Italy. In 927 Hugo, bent on securing support wherever he could, stood godfather to a son of Count Tegrimo, and he endowed the family with certain rights over the abbey of San Salvadore in Agna, near Pistoja. The charter recording this gift was drawn up at Pistoja in the prescnce of Count Tegrimo and Countess Engelrada." We hear no more of Count Tegrimo. After his death his sons Ranieri and Guiclo ( $\dagger$ post 960), dating from Pistoja, made a grant to the canons of the church of San Zeno in that city for the benefit of their parents' souls.' Guido also made a grant to secure the right of burial in the same church for himself and his wife

' Tolosanus, Chronicon, ed. Afittrrelli, 1775, c. 11.

'Fantazzi, Monumenti Ravcunati, Venezia, 1801, i. 105, 107 (13 Sept. 909; 13 Nor. 910).

- Repetti, Disionario geagrafico della Toscana, 1833-45, article Agma (927).

- Rena Camici, Serie degli antichi aluchi e marchesi di Tuscrna, 1789, i. 83 (2 Oct. 942). 
Gervisa, and a third son, Tegrimo, is mentioned. ${ }^{5}$ The time had come when the rural nobles realised the advantages which they derived from a close connexion with the representatives of religion. Many churches and abbeys of northern Italy date their foundation or an increase of their influence to the tenth century; and to the charters granting them possessions, or to entries referring to them, we owe much of the information which enables as to date events and to restore genealogies during this obscure period.

Count Guido, the son of Tegrimo and Engelrada, in 960 increased his power by acquiring rights over property in the valley of the Sieve, which were granted to him by Oberto, the son of king Hugo, who had hecome marquis of Tuscany. ${ }^{7}$ Soon afterwards he was at variance with the archbishop of Ravenna, who disputed his claim to the stronghold of Modigliana. By a document dated 896, the property in question had been bestowed by Engelrada's mother, the widow of Duke Martino, on her son Pietro, a deacon. ${ }^{\text {B }}$ But when the archbishop tried to make good his claim by force of arms Count Guido seized him and conveyed him to a fort below Modiglians, where he kept him imprisoned. Guido's brother Ranieri, who was a deacon at Ravenna, at the same time appropriated valuable property belonging to the church. A popular rising at Ravenne was the result, in the course of which Count Guido and all his offspring were put to death-all, excepting one son, who was saved by his nurse. ${ }^{9}$ This was Tegrimo ( $\dagger$ c. 1(107), surnamed Bevisangue, perhaps on account of the revenge which he afterwards took on the murderel's of his father. In 963 the deacon Ranieri, with his nephew Tegrimo, made over certain property to the archbishop of Ravenna, ${ }^{10}$ but without appeasing him. For in 967, when Otto I, who had been crowned emperor at Rome, presided at a court held at Ravenna, the archbishop lodged a complaint against Ranieri, who had been summoned to synods at Rome, at Classe, and again at Classe, but had disregarded the summons. Judgment was now passed against him, and he was called upon to restore the stolen property at the risk of paying a considerable sum. ${ }^{11}$ Nothing more is recorded of Ranieri. Count Tegrimo retired to the Casentino, a district which embraces the uppermost part of the valley of the Arno, and is rendered remote through the circle of its enclosing mountains; and here on a fruitful upland district he founded the abbey of Strumi, 18 which remained a centre of the Guidi's attention during several

- Ibid. i. 29 (940).

- Fantuzzi, Mon. Rav. i. 876 (20 April 943).

- Repetti, Dis., article Galiga (24 April 960).

- Fantuzzi, Mon. Rav. i. 96 (8 Sept. 896).

- Tolosanus, Chron. c. 11.

1. Mittarelli, A rrales Camaldulorses, Venetiis, 1755, i. 42 (963).

"Fantuzzi, Mon. Rav. ii. 27 (17 April 967).

18 Rena Camioi, Serie, \&c. i. 51 (1021, referring to the toundation). 
centuries. Tegrimo's wife, Gisla, who is designated as the daughter of Marquis Ubaldo, and their son Guido ( $f$ c. 1084) confirmed the abbey in its rights after his death. ${ }^{3}$ The monks of Strumi followed the rale of St. Benedict; they afterwards joined the congregation of Vallombrosa.

Historians of a later date, Villani $(\dagger 1830$ ) and after him Malespini, related that the ancestor of the Guidi came to Italy with Otto I, and that this emperor bestowed on him the stronghold of Modiglizna. The charters quoted show that the Guidi were in Italy before the emperors of the Saxon house came thither, and Villani's statement in itself is untrue, though based on a true estimate of facts. For the date assigned to the donation of Modigliana is 967, the year in which Otto came to Ravenna. The emperors of the Baxon house, when they first came to Italy, saw danger to themselves in the authority which was claimed by the greater barons, and, with a view to checking them, they strove to attach the lesser barons directly to themselves. It is therefore possible that Otto, during his stay at Ravenna, confirmed Count Tegrimo in the possession of a stronghold which he actually held.

Count Gnido, the son of Tegrimo, apprecisted the progressive tendencies of his age and kept on good terms with the ecclesiastics. He was present when the bishop of Fiesole transferred rights at Florence to his nephew. ${ }^{14}$ He made an endowment to the monks of Strumi, dating from his castle at Porciano in $1017 ;^{15}$ he entered into an agreement with the abbot of Santa Reparata near Frenga in 1025 ; and in 1029 he made a further grant to Strumi to benefit the soul of his wife Imelds. ${ }^{16}$ Shortly afterwards he was at Ravenns, where he and his brother-in-law, who was also named Guido, asaisted at a tribunal, and where he swore before the archbishop that ' be would neither take his oath nor fight in a judgment of God ' against him. ${ }^{17}$ The centre of this count's influence was at Pistoje, near which, according to the historian Salvi, he built himself the atrong. hold of Pecunia. ${ }^{18}$ At Pistoja itself he owned a number of houses with a tower close to the city wall, ${ }^{19}$ commanding the gateway which was afterwards known as the Porta Guidi. A large suburb grew up outside this gateway which became an integral part of the city when the town walls were enlarged about the year 1180 . This saburb was known as the rione or quarter of the Guidi, and the

- Rena Camici, Seric, \&c., i. 49 (8 June 1007).

14 Davideohn, Forach. sur alteren Gesch. von Florews, 1896, p. 33 (4 Jan. 1017).

4 Rena Camici, Serie, \&e., i. 50 (18 Nov. 1017).

10 Repetti, Dir. article Harradi (6 Oct. 102.5) ; Rena Osmioi, Sorie, do i. 59 (March 1029).

"Rabeus, Italic. et Ravenn. Uistoria, libri xi. 1782, p. 869 (11 April 1029).

11 Salvi, Delle Historic di Pistoia e Fasioni d' Italia, 16.56, i. 18.

1- Rana Camioi, Soric, do. i. 58 (April 1024), refars to these houses. 
Via Porta Guidi remains to this day and preserves the name of the family with which the rise of the city was closely connected.

The unstable social and political conditions of Italy at this time resulted in a great confounding of lay and ecclesiastical interests. Laymen owned benefices, which they sold to the priests; the priests were generally married, and dealt with what was entrusted to them as though it were their own. A quarrel between a noble and the representatives of the church often resulted in his appropriating ecclesiastical property, sometimes in his taking possession of convent buildings. The first attempts to rouse men's conscience on these matters were due to St. Romuald ( $\dagger$ 1072), the founder of the order of Camaldoli, who spent a long life wandering from place to place attacking the evil practices of priests and monks. The movement he inaugurated found its most zealons champion in St. Peter Damian ( $\dagger 1072$ ), who rose to high dignity in the church ; and it was further developed by S. Giovanni Gualberto, the founder of the order of Vallombrose ( +1079 ).

With these men the Guidi had various relations. The last Count Guido referred to probably favoured St. Romuald, for a son of his, whose name is not recorded, became a follower of St. Romuald and died in the monestery of Val di Castro at a youthful age about the year 1010. He had a vision of death, and miracles happened at his tomb." Two other sons, Guido and Tegrimo, however, drew upon themselves the hatred of Peter Damian. We first hear of them in 1034, when they made a grant to the canons of San Zeno at Pistoja on the occasion of their father's death ; ${ }^{21}$ but Count Guido ( $\uparrow c .1043$ ) afterwards lived in open enmity with the church. Some time during the rule of Gerardo, bishop of Florence, he snatched Empoli from the Pisans, ${ }^{n 2}$ and he recklessly robbed the abbey of Florence. ${ }^{23}$ The account of a vision is preserved which a chaplain had of hell, and which was circulated obviously with a view of intimidating Count Guido and others who acted as he did. The vision was described by Peter Damian, and it told how a chaplain saw Count Ildebrando of the Aldobrandeschi and Count Lotario of the Cadolinghi suffering torments in hell, and how demons of terrible appearance were preparing an empty place for Count Guido, who died shortly afterwards. ${ }^{2}$ The fear of death apparently intimidated him ; for when he lay prostrate on a bed of sicknese, perheps dying. at his stronghold at Vincio, he and his wife Adaletta, who is designated as the duughter of Ildebrando, made orer extensive property, including tenements, vineyards, fields,

- Mittarelli, An. Cam. i. 315.

"Rene Camici, Scrie, dc. i. 58 (April 1034).

"Mittarelli, An. Cam. ii. 97.

- Davideohn, Geschichle ron Florenz, 1896, p. 155.

24 P. Damiani Epist. lib. iv. 7 (written between 1045-1071, Neukirch.), ed Migne. 
meadow.land, and woods, consisting of oak forests and olive groves, at Groppoli, to the canons of Sen Zeno at Pistoja. ${ }^{25}$

Count Guido's brother Tegrimo also drew on himself the anger of Peter Damian. Peter had founded a monastery at Acereta near Faenza, to which he wished to attach a hermitage on the plan of that which Romusld had founded at Camaldoli ; but Tegrimo apparently did not favour the plan. This count ruled the family estates, perhaps, in consequence of his brother Guido's premature death. In 1043 we find him conceding certain rights to the abbey of San Salvadore in Fonte Taona ${ }^{96}$ (this grant speaks of Tegrimo's acting according to Lombard law), and he also confirmed the abbey of Strumi, dating the charter from his own house there in 1048. ${ }^{27}$ But he gave Peter nothing. When Hildebrand, afterwards Pope Gregory VII, was staying in Florence, vassals of the reigning Count Guido ( $\dagger$ a. 1103), the nephew of Tegrimo, appeared before him and accused Peter Damian of building on land near Acereta that was not his. ${ }^{28}$ The matter, however, was amicably settled. An agreement, probably of the year 1063, sets forth that the clarissimus Count Guido, and his wife, the serenissima Countess Ermelina, on the one side, and Peter Damian on the other, fixed the relations of the monastery and hermitage at Acereta, the hermitage being endowed by the count with the income of the church of Ban Donato at Modigliana.9. The further friendly relations of this connt and Peter appear from a letter in which Peter spoke of the present of fish which the count sent him. ${ }^{30}$

Two other sons of Guido and Imelda are mentioned, who acted on their own responsibility, perhaps because they were at variance with their brother Guido. At a meeting convened at Borgo d'Arbia by the imperial representative in 1087, Count Ranieri was present, who is described as the son of Count Guido konac nemoriae." Ranieri afterwards had transactions at Lucca, where we likewise hear of Johsnnes, son of Count Guido. ${ }^{32}$ According to Passerini, Itta, abbess of the monastery of Sun Ellero (S. Ilerio di Alfiano), was a sister of these counts. Itta was brought into close relation with Giovanni Gualberto, the founder of the order of Vallombrosa, who first carried disputes concerning simony into Florence.

About the year 1095 Giovanni, who was then a monk, raised a tumult by accusing various ecclesiastics of simony. He was obliged to fly from Florence, and sought refuge in the hermitage of

2 Rons Canidid, Sorie, dc. i. 63 (23 May 1043).

Iovid. (May 1048).

" Ibid. (March 1048).

- P. Damiani Epist. lib. ii. 9.

- Migne, Patrol. Cursus completius, cxliv. 601 (c. 1088).

- P. Damiani Epist. lib. vi. 19.

s Muratori, Antiquilates Italicae madii aevi, 1738, vol. v. 668 (1037).

- Mittarelli, An. Cam iii., appendix 14 (1045, 1047).

- Panarini, I Conti Guidi, in Litta, Colebri famiglie Italiane, fasc. 150. 
Acqua Bella, high up in the mountains, which lelonged to the convent of San Ellero. Abbess Itta bade him stay at Acqua Bella and provided him with food and with books, and here Giovanni was joined by kindred spirits, with whose help he transformed the hermitage into the monastery which became famous under the name of Vallombrosa. In 1039 Itta, 'prompted to this act by the consciousness of inherent sinfulness,' endowed Giovanni and his monks with extensive property, and the charter which set forth the grant was signed in the presence of numerous witnesses at Florence. ${ }^{34}$

At this time Florence wis a place of comparatively small importance. It had greatly suffered under Lombard rule, and many families had left the city for their neighbouring properties. Under the rule of the Franks, owing chiefly to the natural advantages of its situation, the city began to recover. Measured by the age's rate of locomotion, it was a day's journey from Lucca, the residence of the marquises of Tuscany; a day's journey from Pisa, always a flourishing seaport, and a day's journey from Siena. Thus situated, it became the usual balting-place of the emperors on their way south, and it repertedly offered shelter to the popes when they were unable to maintain their authority against the factions in their own bishopric. Partly owing to the disturbance occasioned by Giovanni, Florence for a time became the headquarters of the reform movement. In 1055 a church council was convened here, which the emperor, the pope, and more than a hundred ecclesiastics attended. All eyes for a time were turned to the city on the Arno. In 1058 the bishop of Florence became pope under the name of Nicholes II ( $†$ 1061), but he retained his old see and usually resided at Florence. About the same time Bonifazio, the marquis of Tuscany, died. His widow Beatrice fortified her position by marrying Godfrey, the duke of Lothringen, and she also frequently resided at Florence.

One of the functions of the marquis consisted in presiding at the courts which were periodically held in the different cities of Tuscany, at which he appeared surrounded by his feadatories while the more influential citizens conducted the trial. At a court held by Beatrice in the episcopal palace at Florence in 1061 Count Guido was among those who attended. ${ }^{35}$ Unlike his father, this count was on good terms with the ecclesiastics. In 1056 he had transactions with the abbot of the convent of Marturi which lay on the way to Siena; and he made a grant of property to the monks of Fonte Trona. ${ }^{\text {; }}$ In 1062 he added to his possessions in the Val di Sieve by purchasing the lands and the

"Lami, Sanctac Ecclesian Flor. monumonta, 1758, i. 676 (B Joly 1039).

"Rena Camici, Seric, cc. vol. ii. pt. 2, p. 108 (December 1061).

* Ibid. i. 71 ff. (28 March and April 1056).

VOL. XIV.- No. LTV. 
stronghold of Nipozzano." Ston afterwards he came ander the full influence of the reform movernent.

When Pope Nicholas died in 1061, the of Rome and of Florence were both vacant, and the reactionary party secured the bishopric of Florence for Pietro Mezzabarba, who paid hesvily for his appointment. This at once drew on him the opposition of Giovanni Gualberto and of the Vallombrosan monks, who now owned the convent of San Salvi near Florence, and who stood organised as a political party. It was in vain that the bishop made an armed attack on San Salvi, hoping to take Giovanni prisoner. Gioranni escaped ; but the people of Florence would not be pacified. They demanded that a judgment of God should decide as to the bishop's guilt, and after a lay brother of San Salvi had passed unhurt between two flaming fires, there was no resisting the popular movement. Bishop Pietro was deposed, and the cause of Giovanni grew in favour. Cnder the influence of this feeling, Count Guido restored to the albbey of Florence the property which his father had seized, together with gold, silver, and jewels; ${ }^{28}$ he bestowed an estate at Trbora on Giovenni and his monks, ${ }^{39}$ and he founded and endowed a hospital at Florence at the request of the abbot of San Miniato." In the charter relating to this latter grant he declared that he was prompted to make it 'by the thought of hell and of fire burning with brimstone most terrible in its stench.' The spirit which moved him took possession slso of the rulers of Tuscany, of Beatrice and her danghter Matilda-the Great Countess, as sho was usually called. Pope Alexander, after deposing the bishop of Florence, came to Lucca, where be was received by these ladies, and Count Guido also was in attendance." Guido was also present at a court held in Florence by Bestrice and Matilda in 1072. ${ }^{42}$ After the death of Beatrice, Matilda ruled alone. She fervidly embraced the cause of reform and became the enthusiastic admirer of pope Gregory VII. And when jealousy of this pope's pretensions stirred the emperor to wrath, Matilda, departing from the allegiance which she owed to the emperor in her capacity as raler of Tuscany, threw in her lot with the pope.

In these conflicts Count Guido no doubt sided with Matilda, though it is not expressly stated that he bore arms against the emperor, who carried war into Tuscany. Nothing is recorded

" Kena Camici, Serie, dc. i. 78 (November 1062).

- Devideohn, (taxchrchte, pp. 155, 762 (October 1066). The amount is differently quoted : 'Per libras 30 denar. Lucens.' is probably correct.

- Rane Camici, Soric, ac. iv. It (May 1068).

to Lami, S. Biceles. F'lor. Mon. I. 29 (Jannary 1069).

1 Rena Camici, Seric, \&c. ii. pt. 2, p. 116 (8 Jaly 1038).

" Ibid. ii. $\theta$ (March 1072). 
concerning the share which he doubtless took in the campaigns of these years, and all we know is that in 1081 he invested the monks of Vallombrose with lands which belonged to the convent of San Ellero, ${ }^{43}$ and in 1084 made a grant to San Benedetto negl' Alpi." The Great Countess for a time was hard pressed, for many cities of Tuscany profited by the einperar's appearance to revolt against the rule of the marquises. Florence alone held with her. But among the cities which soon went over to her side was Pistoja, and here we know the Gaidi's inflnence to bave been great. The order of Vallombrosa gained its first foothold here owing to the protection it found with Pietro ( $\nmid 1105)$, who was probably the brother of the reigning Count Guido. He had founded the convent of Ban Michele in Forcole which now passed into the hands of the Vallombrosan monks 'at the request of some of the most influential citizens.' 's) In 1085 Bishop Leo, ' in the presence and with the consent of Matilds and Count Guido,' framed new injunctions for his clersy, ${ }^{46}$ a proof that the reform movement was gaining ground, and when Loo died, he was succeeded by Pietro, who was appointed in an uncanonical manner through the influence of Matilda, but afterwards confirmed by the pope.

All the monasteries of which the Guidi were patrons or in which they had influence before the close of the century joined the order of Vallombrose. Among them was Strami in the Casentino, where some of the literary activity was displayed which rendered the Vallombrosan order famous. Andrea of Parma, the author of the Life of St. Areald and of the Life of St. Giovenni Gualberto, became abbot here. Andrea enjoyed the esteom of Connt Guido, from whom he received several grants, one to benefit the soul of Countess Ermelina, in 1094. ${ }^{47}$ This lady's name figured by the side of her husband's in most of the charters granted by him, for the last time in $1086 ;^{* A}$ and besides Andrea, the canons of Sen Zeno at Pistoja received a grant for the benefit of her soul."

Towards the close of the century, the thought of the Crusade gare a new direction to men's love of enterprise. The Crusade was advocated by the Grest Countess, and among those who joined it was Guido-not the reigning count, but his son, for the cruseders left Italy early in 1097, and several charters of that and the following year prove the continued presence of Count Guido, the father, in Italy. Young Guido was married before 1096 to Imilia,

- Rena Camici, Serie, do. iv. 17 (90 Dec. 1081).

4 Mittarelli, An. Cam. iji. 24 (1084).

4 Selri, Hist. Pist. i. 50 (Beptember 1084).

- Rens Camici, Seric, dc. vol. iii. pt. 2, p. 70 (10 April 1085).

47 Ammirato, Albero e istoris della famiglia de' Conti (tuidi, 1640, p. 3 (November 1040). Rena Caroici, Serie, to. vol. iii. part 4, p. 56 (Novembar 1094).

14 Mittarelli, An. Cam vol. iii. sppendir 85 (1086).

- Rena Camici, Serie, dec. vol. iii. part 4, p. 59 (21 Jan. 1096). 
the daughter of Rainaldo called Sinibaldo: ${ }^{\circ}$ Details contained in various charters show that he started for Palestine with his brother Tegrimo, that they were cast into prison, and that only Guido returned to Tuscany.

A charter granted by Count Guilo in July of 1097 contains some interesting particulars. It bestowed their freedom on two brothers 'according to the writ promulgated by king Liutprand' (that is, according to Langobard law), for the benefit of the soul of Ranieri, the son of Guido. The ceremony of emancipation in this case consisted in the brothers walking three times round the altar of the Virgin in the church of Montedicroce. The count then handed them over to the priest and declared them free. ${ }^{31}$ Another parchment of the same year recorded that Count Guido, being guilty of the murder of a certuin Uberto di Pepo, bestowed an estate in atonement for his crine on the son and the brother of the murdered man, and that this estate was now transferred to the canons of Pistoja. ${ }^{32}$

In the course of the year 1098 Count Gaido fought in support of the inhabitants of Faenza. They rose and expelled their ruling count, who fled to the stronghold of Belvamaggiore, which the men of Faenza, with Guido's help, attacked, seized, and dismantled.s3 A number of documents dating from the next few years show how the count's private affairs and public duties took him from place to plnce. In June of $\mathbf{1 0 9 8}$ he stayed at Strumi, and entered into an agreement concerning property at Majona with the provost of Arezzo. ${ }^{\text {H }}$ In the following May he first stayed at Florence with the Great Countess,"ss and afterwards at Pistoja, where he mortgaged land to the canons of San Zeno, and perhaps pawned a silver crucifix of great value in order to raise the necessary sum to pay for the ransom of his sons, who were imprisoned. The Grest Countess at this time entirely regained her hold on Tuscany, and was busy in reorganising the affairs of church and state. In June 1099 she was at Lucca and gave judgment in favour of Bishop Rugger, whose claim to some property Count Guido disputed; a week later Guido was in attendance on her at Marturi.57 Shortly afterwards young Guido returned from Palestine, for he was with his father at Pistoja in July of 1099, when certain rights were conceded to Teberga, abbess of the convent of Ban Mercuriale; and again in September, when extensive property was bestowed on

- Mlittarelli, An. Cam. iii. 235.

\$1 Reda Camici, Serie, \&c. vol. iii. part 4, p. 71 (July 1097).

"Ibrid. p. 74 (December 1097).

Tolosanus, Chrom. c. 25 (1008).

s Mittarelli, An. Cam. iii. appendix 140 (June 1098).

s Repetti, Dis. artiole Campiano (2 May 1099).

- Devidsohn, Qeschichte, p. 284 (28 May 1099).

"7 Rens Camici, Seric, tc. vol. iii. part 4, pp. 88, 88 (June 1099).

s Repetti, Dis. article Germinaja (July 1099). 
the abbersis Berta (bere called Uberta) of Rosano, who was daughter to the one count and sister to the other.5 Both counts then joined Matilda at the monastery of San Salvadore in Fonte Taona, ${ }^{511}$ and in acknowledgment of the services which the Guidi had rendered to her, the Great Countess formully adopted young Guido as her son : he is so designated in a charter of October which was drawn up when he and his father stayed with the countess at San Brescello in Lombardy. ${ }^{61}$ In consequence of this adoption the young Count assumed the title of marquis, which he bore in the charter granted to Rosano, and also in a ducument in which he referred to a grant made for the benefit of his brother Tegrimo's soul to Strumi. ${ }^{62}$ During these years the Guidi were closely connected with the Great Countess, and one of them in the autumn of the year 1099 was despatched south in order to support Pope Pasohal II. ${ }^{\text {.5 }}$ But young Guido soon dropped the title of marquis, for reasons which are not recorded, but which were doubtless connected with Matilda's making a berguest (1102) by which her vast possessions went to the church. In ordinary parlance Guido seems to have kept the title, but in the documents in which his name officially appeared he was henceforth called Guidoguerra or simply Guido. Still his friendly relations with Matilda remained undisturbed. After so many grants made to the order of Vallombrosa, he and his father finally joined the countess in taking the congregation under their direct protection; in the charter in which this was set forth the Counts Guido and Guidoguerru were named by the side of Matilda as though they shared her anthority in full. ${ }^{-A}$ The elder count then either died or else gave over the management of his affairs to his ann, who now granted land at Montemurlo to Raimondino, ' in recognition of the services which you rendered me on the journey to Jerusalem.' Guido postponed redeeming the estates and the crucifix which his father had mortgaged to the canons of Pistoja when his sons were imprisoned, ${ }^{66}$ and two years afterwards he further delayed and then altogether renounced his claims to this property. In the second of these charters he referred to his father as no longer among the living. ${ }^{67}$ We gather from these charters that Guido il marchese was unable to write his name, and therefore put a cross

- Mittarelli, An. Cant. iii. 88 (Bept. 1099).

- Maratori, Anliquilates, i. 414 (6 Bept. 104:)).

- Fiorentino Mansi, Mcmoric di Malehla, 1042, ii. 158 ('Glias adoptjuas,' 12 Oct. 1099).

- Rena Camici, Serie, do. iv. $59(1100)$.

a Davideohn, R., Forachungen, p. 65.

4 Rena Camici, Serie, \&c. iv. 57 (1100).

- Repetti, Lis., article Hontomutrla. Davidsohn, Borschungen, p. 65 (November $1100)$.

- Rena Camici, Serie, \&ec. iv. 65 (November 1100).

- 1bid. iv. 85, 87 (August and October 1103). 
in place of his signature; in a document of 1108 words are added to the effect that he wished the grant to be set forth in writing, but that he was unable to sign it. In the course of the year the count fought in Romagna in the interest of Frenza, which, in common with other cities of northern Italy, was awaking to a desire of municipal freedom.

The inhabitante of many Italian cities at this time were becoming restive in view of the pretensions of the counts who had been thrust upon them during a period of political insecurity. It has been mentioned that the citizens of Frensa in 1098 expelled the ruling count, and that Count Guido at the time supported them. In 1103 they were again in revolt and expelled a number of nobles, who fled, some to the stronghold of Cunio, others to Ravenna. The archbishop of Ravenna had the right of appointing a count to the city of Frenza, and he watched the city's manifestations of growing independence with anxiety. He now provided the expelled nobles with money and with troops, and they returned and laid siege to Faenza, ' insulting the citizens by bathing in the river, by playing games under the city walle, and by getting fire to the bridge.' The citizens in their distress sent a message to Count Guido, and they greeted his appearance as though he were ' an angel sent by God.' On the news of his approach some of the besiegers fled; the others he defeated. ${ }^{\oplus}$ The count then returned to Strumi, where he gave his consent that his wife, Imilia, should bestow all the estates she received as 'morgincap' on the monks of Strumi ; ${ }^{70}$ and stter that he was in Lombardy, where he witnes a grant made by Matilda."

A rising about the same time ocourred at Pistoja, where a number of noble families were forced to leave the city in consequence of the disturbances there. Here Bishop Pietro of the Guidi threw in his influence with the people, and, 'assisted by the arm and the authority of the consuls,' he succeeded in restoring order. 'The bishopric of Pistoje suffered terribly during the wars between the emperor and Matilda, but under the rule of Pietro, and of Ildebrando (1105-1183), his nephew and successor - who was perhaps the brother of Guido il marchese-the possessions which had been lost to the see were ragained. In 1107 Bishop Ildebrando and his men joined the troops which the countess led against Prato, which had rebelled. ${ }^{\text {"n }}$ The reason of the disaffection of Prsto is unknown. The Counts Alberti were the lords of the place, bat if we credit the account given by Villani, the Guidi had a personsl interest in its being reduced to submission. For

\footnotetext{
- Ildefonso di than Inigi, Delirie degli eruditi, 1770, viii. 163 (18 Nov. 1103).

- Tolosanus, Chrun. o. 19 (1103).

- Rena Camioi, Serie, kec. iv. 80 (31 Jan. 1104).

" Tbid. p. 92 (24 April 1104).

"Z Balvi, Bist. Pist. i. 68 II.
} 
Villani records (and the acconnt finds corroboration elsewhere) that the inluatsitants of Prato were originally followers of the Guidi and dwelt on Monte Chiavello, near Montemurlo, which they left in order to live under nuore favourable conditions at Prato."

Count Guido's relations with Pistoja were of the friendliest. A large part of the city being destrojed by fire, Bishop Ildebrando set about rebuilding the church of San Zeno, henceforth the cathedral, in the form which it retains to the present day. In order to assist him in doing so, Guido and his wife Imilia, writing from Montedicroce, made grant of property and promised in no way to interfere with the plan of bringing down the waters of the river Ombrone into the city by means of a conduit. They also accorded their protection to the churches of San Giovanni Fuorcivitas and of San Mercuriale." Various transactions dating from these years prove the count's friendly relations with the order of Camaldoli." Count Gaido was probably in attendance on Matilda for the last time on 11 Oct. 1108 at the monastery of San Benedetto near the river Larione, to which they conjointly made 8 grant. ${ }^{78}$ The Great Countess ceased to take an active part in affairs some years previous to her death (1115), and the various cities of Tuscany were left unimpeded to pursue the course of development on which they had embarked.

Florence at this time advanced by leaps and bounds. The city which Peter Damian in 1065 characterised as a poor place of fow inhabitants, profited by the wars when the Great Countess's attention was engaged elsewhere, and the citizens took the management of affuirs into their own hands. It is impossible to assign a date to the birth of the Italian commune, for the conditions which drew the citizens together and prompted them to concerted action varied in each case; but in Florence the establishment of the commune was directly connected with the wars waged by the Great Countess, which threw the citizens on their own resources and stimulated them to independent activity. In Florence as elsewhere the citizens were divided according to their occupations. There were the lesser citizens, whose activity was largely industrial, and the grester citizens, who often drew an income from their outlying properties. These represented the oldest Italian families: some of them in fact claimed Roman descent. But they were not titled, and this helps us in distinguishing them from the nobles of barbarian origin, such as the Guidi, who, by reason of being invaders, were in possession of the outlying

n Villani, Istorie Fiorentine, book iv. ch. 25; O. Hartwig, Quellen und Forochungen rur llltesten Oezchichte own wherza, 1875, ii. 49 ff.

"Salvi, Hist. Pist. i. fon.

"Mittarelli, An. Cain. iii. 234 (1109, 1115, 1116, 1117).

To Lena Camici, Soric, de. vol. iv. part 2, p. 3 (16 Oct. 1108). 
districts, but who as yet hal no fuothold inside the city of Florence. Their introduction into the city marked the beginning of a new chapter in its history.

The hills which surround Florence loristled with the strongholds of nobles, who were ready to swoop down und plunder the bands of passing traders on the slightest pruvocation. In the interest of its industrial and commercial future the city was obliged to protect itself against these attacks. Even before the death of the Great Conntess the Florentines attacked and secured the fort of Monte Gualandi or Orlandi, which lay on the road to Pisa, and then laid siege to the stronghold on Monte Cascioli. The annalist of Siena states that the Florentines in 1114 suffered a defeat near Montedicroce, the stronghold of Count Guido, at the hands of the men of Siene and of Count Guido." But as nothing is known concerning hostilities between Siena and Florence at this time, and the entry is worded exactly like one of 1146, its information is open to question. However, Count Guidu was fully awnre of the danger which threatened him through the growing power of Florence, and, with a view to strengthening his own position, he fortified the height of Montemurlo, which was situated on the limits of the territories of Pistoja and Florence; and he entered into an agreement with the provost of the church of Sant' Andrea at Empoli which throws an interesting light on the way in which the rural nobles strengthened their local influence. The church of Sant' Andrea stood somewhat removed from the town, and Guido bestowed land sufficient to build a house on all who agreed to come and live near this church. He then constructed a stronghold for the better defence of the place, and he pledged himself to rebuild the houses of the inhabitents should they suffer in times of war. Countess Imilia contirmed this charter at Pistoja in 1119. ${ }^{7}$ O wing to these advantages, the city of Empoli entered on a course of development which secured to Count Guido the reputation of being the founder of the place. The number of its inhabitants and the productiveness of the surrounding district so rapidly increissed that Empoli was afterwards called the granary of Florence. During these years Guido also drew closer to the bishop of Lucca, who was at variance with the bishop of Florence concerning property at Fucecchio, to which both bishops laid claim, its owners, the Counts Cadolinghi, having failed in the direct line. Count Guido bestowed half of the rights he owned at Fucecchio on the bishop of Lucca, 79 and he afterwards took the monastery of Ban Salvadore under his special protection. ${ }^{80}$

After the death of Matilda, several marquises of Tuscany came

\footnotetext{
"Monumenta Germanize historica, xix. 225: 'An. Sen.' (28 Jane 1114).

"Repetti, Dix., article Émpuli (Deceunber 1119).

- Davidsohn, Forsclinngen, p. 8! (3 Nov. 1114).

- Ibid. p. 90 (12 Dec. 1122).
} 
and went who exerted little influence on the state of affairs. The dignity in itself cersed to be hereditary. In 1120 Count Guido was in attendance on the marquis Conrad who laid siege to Pontormo and there granted certain liberties to the city of Lucca, the charter of which Guido witnessed. ${ }^{81}$ Guido aleo stayed with Conrad at the monastery of Sun Lorenzo di Coltibuona two years later. ${ }^{89}$ The last we hear of him is that he joined the citizens of Faenza in an expedition which they undertook with a view to seizing the stronghold of Cunio. ${ }^{\text {.3 }}$ He died in the course of this campaign, and in October of 1124 Countess Imilia referred to him as no longer among the living. ${ }^{\text {st }}$

\section{Lina Echengtenn.}

$$
\text { (To be continuted.) }
$$

n. Davidsohn, Gesclichte, p. 390 (2 Oct. 1120).

* Rene Camici, Seric, \&c. vol. vi. pt. 2, p. 46 (1122).

"Tolosanas, Chron. c. 21 (1121). "Davideohn, Geschichte, p. 395, footnote. 